\title{
Analysis of the impact of reclamation project on the health of Marine ecosystem in Cangzhou coastal area
}

\author{
Wang Ning ${ }^{1}$, Liu Bin ${ }^{1, *}$, and Shou Youping ${ }^{1}$ \\ ${ }^{1}$ Laboratory of Waterway Environmental Protection Technology, Tianjin Water Transport Engineering Science Research Institute, \\ Tianjin 300456, China
}

\begin{abstract}
For a comprehensive understanding of Cangzhou nearshore reclamation project construction effect on Marine ecosystem health, the evaluation scope is divided into six areas. According to the spring monitoring data in 2017, the regional ecosystem health evaluation method is used to evaluate the health index, and five evaluation indexes including seawater environment, sediment environment, biological habitat, biological forms and organisms are selected. Studies have shown that: the seawater environment, sediment environment and biological forms in the Cangzhou coastal area were all healthy; biological habitats, organisms and marine ecosystems were Unhealthy or sub-healthy; Reclamation activities are associated with the deterioration of seawater quality and the reduction of benthic and plankton biomass. The destruction of biological habitats is the main reason for the low ecosystem health index.
\end{abstract}

\section{INTRODUCTION}

For a long time, reclamation has been regarded as an important way to solve the shortage of land resources in coastal areas. Since the late 1990s, large-scale reclamation has been mainly used for engineering purposes, such as port construction, ship repair and airport construction, industrial purposes, such as steel production and oil storage, and residential development and construction. At the same time of forming remarkable social and economic benefits, the disorderly, unrestrained and free reclamation also brings serious negative impact on the Marine environmental resources in coastal areas [1-3].

From a single project in the early days to a largescale regional reclamation, the sea area is facing increasing risks of high pollution and Marine ecological damage while making remarkable progress. [4-5].

Cangzhou is located in the eastern part of Hebei province, near the border of Shandong Province. Cangzhou Bohai New Area began large-scale reclamation in 2007, and by 2016 the reclamation activities had basically ceased, with a total reclamation area of 76 square kilometers. With the expansion of the reclamation area, a series of ecological problems, such as the change of the natural properties of coastal zones and the reduction of coastal wetlands, have been brought about. In order to rationally develop and utilize marine resources and protect marine ecosystem, it is urgent to carry out health assessment of marine ecosystem in the coastal areas of Cangzhou.

\footnotetext{
* Corresponding author: 635803523@qq.com
}

\section{METHODS}

In order to reflect the impact of reclamation activities on the marine ecosystem, the assessment scope was divided into six areas and numbered as Area I, II, III, IV, V and VI. All the reclamation areas are located in area III.

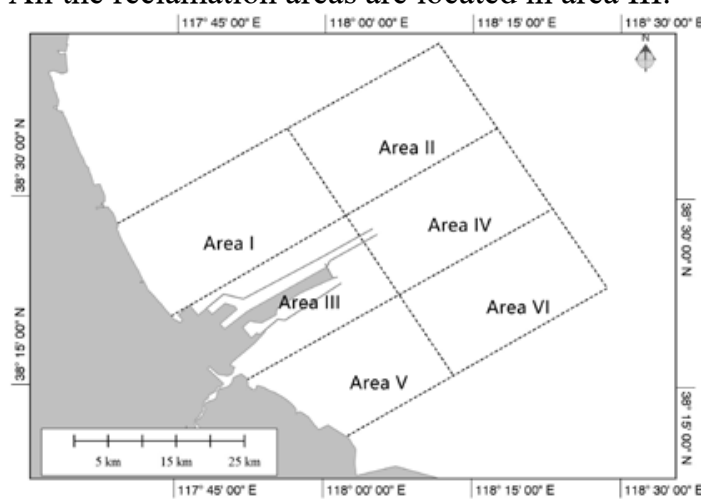

Figure 1. Cangzhou coastal area division map.

Based on spring monitoring data of Cangzhou coast area in 2017, this study constructed the marine ecosystem health evaluation index system.

\subsection{Classification and weight of evaluation index}

According to the "eco-environmental health assessment method for estuarine and Gulf ecosystems" in the 《 Guidelines for Evaluation of Nearshore Marine Ecological Health》 (HY/T 087 -- 2005), 5 kinds of evaluation indexes were selected: seawater 
environmental index, sediment environmental index, biological habitat index, biological forms index and organisms index.

\subsection{Research methods}

The indicators, requirements and valuations of estuaries and bays are shown in Table 2 .

Table 1. Indicators and weights for evaluating ecosystem health in estuaries and bays

\begin{tabular}{|c|c|c|c|c|c|}
\hline Evaluation index & Seawater environment & Sedimentary environment & Biological forms & Biological habitat & Organisms \\
\hline Weight & 15 & 10 & 10 & 15 & 50 \\
\hline
\end{tabular}

Table 2 Criteria for evaluating ecosystem health in estuaries and bays

\begin{tabular}{|c|c|c|c|}
\hline Evaluation index & \multicolumn{3}{|c|}{ level } \\
\cline { 2 - 4 } & healthy & sub-healthy & unhealthy \\
\hline Seawater environment $\left(\mathrm{W}_{\text {indx }}\right)$ & $11 \leq \mathrm{W}_{\text {indx }} \leq 15$ & $8 \leq \mathrm{W}_{\text {indx }}<11$ & $5 \leq \mathrm{W}_{\text {indx }}<8$ \\
\hline Sedimentary environment $\left(\mathrm{S}_{\text {indx }}\right)$ & $7 \leq \mathrm{S}_{\text {indx }} \leq 10$ & $3 \leq \mathrm{S}_{\text {indx }}<7$ & $1 \leq \mathrm{S}_{\text {indx }}<3$ \\
\hline Habitat $\left(\mathrm{H}_{\text {indx }}\right)$ & $11 \leq \mathrm{H}_{\text {indx }} \leq 15$ & $8 \leq \mathrm{H}_{\text {indx }}<11$ & $5 \leq \mathrm{H}_{\text {indx }}<8$ \\
\hline Biological forms $\left(\mathrm{B}_{\text {indx }}\right)$ & $7 \leq \mathrm{B}_{\text {indx }} \leq 10$ & $4 \leq \mathrm{B}_{\text {indx }}<7$ & $1 \leq \mathrm{B}_{\text {indx }}<4$ \\
\hline Organisms $\left(\mathrm{O}_{\text {indx }}\right)$ & $35 \leq \mathrm{O}_{\text {indx }} \leq 50$ & $20 \leq \mathrm{O}_{\text {indx }}<35$ & $10 \leq \mathrm{O}_{\text {indx }}<20$ \\
\hline Marine ecological health index $\left(\mathrm{CEH}_{\text {indx }}\right)$ & $\mathrm{CEH}_{\text {indx }} \geq 75$ & $50 \leq \mathrm{CEH}_{\text {indx }}<75$ & $\mathrm{CEH}_{\text {indx }}<50$ \\
\hline
\end{tabular}

Table3 Environmental assessment indicators, requirements and values for estuaries and bays

\begin{tabular}{|c|c|c|c|c|}
\hline & Indicators & $\mathrm{I}$ & II & III \\
\hline & Assignment & 15 & 10 & 5 \\
\hline \multirow{5}{*}{$\begin{array}{c}\text { Seawater } \\
\text { environment }\end{array}$} & Dissolved oxygen $(\mathrm{mg} / \mathrm{L})$ & $\geq 6$ & $\geq 5 \sim<6$ & $<5$ \\
\hline & $\mathrm{pH}$ & $>7.5 \sim \leq 8.5$ & $>7.0 \sim \leq 7.5$ or $>8.5 \sim \leq 9.0$ & $\leq 7.0$ or $>9.0$ \\
\hline & reactive phosphate $(\mu \mathrm{g} / \mathrm{L})$ & $\leq 15$ & $>15 \sim \leq 30$ & $>30$ \\
\hline & Inorganic nitrogen $(\mu \mathrm{g} / \mathrm{L})$ & $\leq 200$ & $>200 \sim \leq 300$ & $>300$ \\
\hline & Petroleum $(\mu \mathrm{g} / \mathrm{L})$ & $\leq 50$ & $>50 \sim \leq 300$ & $>300$ \\
\hline \multirow{2}{*}{$\begin{array}{l}\text { Sedimentary } \\
\text { environment }\end{array}$} & Organic carbon & $\leq 2.0 \%$ & $>2.0 \% \sim \leq 3.0 \%$ & $>3.0 \%$ \\
\hline & Sulfide $(\mu \mathrm{g} / \mathrm{g})$ & $\leq 300$ & $>300 \sim \leq 500$ & $>500$ \\
\hline \multirow{5}{*}{$\begin{array}{l}\text { Biological } \\
\text { forms }\end{array}$} & $\mathrm{Hg}(\mu \mathrm{g} / \mathrm{g})$ & $\leq 0.05$ & $>0.05 \sim \leq 0.10$ & $>0.10$ \\
\hline & $\mathrm{Cd}(\mu \mathrm{g} / \mathrm{g})$ & $\leq 0.2$ & $>0.2 \sim \leq 2.0$ & $>2.0$ \\
\hline & $\mathrm{Pb}(\mu \mathrm{g} / \mathrm{g})$ & $\leq 0.1$ & $>0.1 \sim \leq 2.0$ & $>2.0$ \\
\hline & As $(\mu \mathrm{g} / \mathrm{g})$ & $\leq 1.0$ & $>1.0 \sim \leq 5.0$ & $>5.0$ \\
\hline & $\begin{array}{l}\text { Petroleum hydrocarbons } \\
(\mu \mathrm{g} / \mathrm{g})\end{array}$ & $\leq 15$ & $>15 \sim \leq 50$ & $>50$ \\
\hline \multirow{2}{*}{ Habitat } & $\begin{array}{l}\text { Coastal wetland habitat } \\
\text { decreased in } 5 \text { years } / \%\end{array}$ & $\leq 5$ & $>5 \sim \leq 10$ & $>10$ \\
\hline & $\begin{array}{l}\text { Annual variation of major } \\
\text { components in sediment } / \%\end{array}$ & $\leq 2$ & $>2 \sim \leq 5$ & $>5$ \\
\hline \multirow{7}{*}{ Organisms } & $\begin{array}{l}\text { Phytoplankton density } \\
\left(\text { ind } / \mathrm{m}^{3}\right)\end{array}$ & $>50 \% \mathrm{~A} \sim \leq 150 \% \mathrm{~A}$ & $\begin{array}{c}>10 \% \mathrm{~A} \sim \leq 50 \% \mathrm{~A} \\
\text { or }>150 \% \mathrm{~A} \sim \leq 200 \% \mathrm{~A}\end{array}$ & $\leq 10 \% \mathrm{~A}$ or $>200 \% \mathrm{~A}$ \\
\hline & Zooplankton density $\left(\mathrm{ind} / \mathrm{m}^{3}\right)$ & $>75 \% \mathrm{~B} \sim \leq 125 \% \mathrm{~B}$ & $\begin{array}{c}>50 \% \mathrm{~B} \sim \leq 75 \% \mathrm{~B} \\
\text { or }>125 \% \mathrm{~B} \sim \leq 150 \% \mathrm{~B}\end{array}$ & $\leq 50 \% \mathrm{~B}$ or $>150 \% \mathrm{~B}$ \\
\hline & Zooplankton biomass $\left(\mathrm{mg} / \mathrm{m}^{3}\right)$ & $>75 \% \mathrm{C} \sim \leq 125 \% \mathrm{C}$ & $\begin{array}{c}>50 \% \mathrm{C} \sim \leq 75 \% \mathrm{C} \\
\text { or }>125 \% \mathrm{C} \sim \leq 150 \% \mathrm{C}\end{array}$ & $\leq 50 \% \mathrm{C}$ or $>150 \% \mathrm{C}$ \\
\hline & $\begin{array}{l}\text { Density of fish eggs and larvae } \\
\left(\mathrm{ind} / \mathrm{m}^{3}\right)\end{array}$ & $>50$ & $>5 \sim \leq 50$ & $\leq 5$ \\
\hline & Benthic density $\left(\mathrm{ind} / \mathrm{m}^{2}\right)$ & $>75 \% \mathrm{D} \sim 125 \% \mathrm{D}$ & $\begin{array}{c}>50 \% \mathrm{D} \sim \leq 75 \% \mathrm{D} \\
\text { or }>125 \% \mathrm{D} \sim \leq 150 \% \mathrm{D}\end{array}$ & $\leq 50 \% \mathrm{D}$ or $>150 \% \mathrm{D}$ \\
\hline & Benthic biomass $\left(\mathrm{mg} / \mathrm{m}^{2}\right)$ & $>75 \% \mathrm{E} \sim \leq 125 \% \mathrm{E}$ & $\begin{array}{c}>50 \% \mathrm{E} \sim \leq 75 \% \mathrm{E} \\
\text { or }>125 \% \mathrm{E} \sim \leq 150 \% \mathrm{E}\end{array}$ & $\leq 50 \% \mathrm{E}$ or $>150 \% \mathrm{E}$ \\
\hline & \multicolumn{4}{|c|}{$\begin{array}{l}\text { Note: According to Appendix A of 《The Guideline for Evaluation of Coastal Marine Ecological Health》, the } \\
\text { values of Bohai bay in May were taken with reference to: } A=3 \times 10^{5} \mathrm{ind} / \mathrm{m}^{3} ; \quad B=10 \times 10^{3} \mathrm{ind} / \mathrm{m}^{3} ; \quad C=400 \\
\mathrm{mg} / \mathrm{m}^{3} ; \quad \mathrm{D}=150 \mathrm{ind} / \mathrm{m}^{2} ; \quad \mathrm{E}=25 \mathrm{~g} / \mathrm{m}^{2}\end{array}$} \\
\hline
\end{tabular}

\subsection{Index assignment calculation and health evaluation method}

The calculation formula of index assignment is:

$$
W_{q}=\frac{\sum_{1}^{n} W_{i}}{n}
$$

$\mathrm{W}_{\mathrm{q}}$ the $\mathrm{q}$ indexes assignment;

$\mathrm{Wi}$ - the evaluation index of item $\mathrm{Q}$ of station I; 
$\mathrm{N}$ - the total number of monitoring stations in the evaluation region.

The formula for calculating the index health index is:

$$
W_{\text {indx }}=\frac{\sum_{1}^{m} W_{q}}{m}
$$

$\mathrm{W}_{\text {indx }}$ the environmental health index;

$\mathrm{W}_{\mathrm{q}} \longrightarrow$ the evaluation index of item $\mathrm{Q}$;

$\mathrm{M} \longrightarrow$ the total number of evaluation indicators in the evaluation region.

The ecological health index is calculated as follows:

$$
C E H_{\text {indx }}=\sum_{1}^{p} I N D X_{i}
$$

$\mathrm{CEH}_{\text {indx }}$ the ecological health index;

$\mathrm{INDX}_{\mathrm{i}} \longrightarrow$ the health index of the category I index;

$\mathrm{P} \_$the total number of evaluation index.

\section{RESULTS AND DISCUSSION}

\subsection{The seawater environment}

Cangzhou nearshore index of seawater environment evaluation results are shown in table 4 , from which it can be seen that, the seawater environment is in a healthy state, and the health index of area III (reclamation area) is the lowest. The analysis shows that the increase of human activities in the reclamation area leads to the increase of the concentration of active phosphate and petroleum. thus resulting in the lower seawater environmental health index.

Table 4 Evaluation of seawater environment health index

\begin{tabular}{|c|c|c|c|c|c|c|c|}
\hline \multirow{2}{*}{$\begin{array}{c}\text { Area } \\
\text { code }\end{array}$} & \multicolumn{4}{|c|}{ Target assignment } & \multirow{2}{*}{$\begin{array}{c}\text { Seawater } \\
\text { Environmental Health } \\
\text { Index }\end{array}$} & level \\
\cline { 2 - 6 } & $\begin{array}{c}\text { Dissolved } \\
\text { oxygen }\end{array}$ & $\mathrm{pH}$ & active phosphate & $\begin{array}{c}\text { Inorganic } \\
\text { nitrogen }\end{array}$ & Petroleum & & \\
\hline Area I & 15.00 & 15.00 & 15.00 & 5.00 & 13.75 & 12.75 & healthy \\
\hline Area II & 15.00 & 15.00 & 15.00 & 5.00 & 15.00 & 13.00 & healthy \\
\hline Area III & 15.00 & 15.00 & 14.44 & 5.00 & 12.78 & 12.44 & healthy \\
\hline Area IV & 15.00 & 15.00 & 15.00 & 5.00 & 15.00 & 13.00 & healthy \\
\hline Area V & 15.00 & 15.00 & 15.00 & 5.00 & 14.00 & 12.80 & healthy \\
\hline Area VI & 15.00 & 15.00 & 15.00 & 5.00 & 15.00 & 13.00 & healthy \\
\hline
\end{tabular}

\subsection{The sediment environment}

Cangzhou nearshore index of sediment environment evaluation results are shown in table 5 ,. from which it can be seen that, the sediment environment is in a healthy state, and there is no significant difference between different areas.

\subsection{Biological forms}

Cangzhou nearshore index of biological forms evaluation results are shown in table 6 . It can be seen from table 6 that the biological forms is in a healthy state, and there is no significant difference between different regions.

Table 5 Evaluation of sediment environment health index

\begin{tabular}{|c|c|c|c|c|}
\hline \multirow{2}{*}{ Area code } & \multicolumn{2}{|c|}{ Target assignment } & \multirow{2}{*}{ Sediment environmental health index } & \multirow{2}{*}{ level } \\
\cline { 2 - 3 } & Sulfide & Organic carbon & 10 & healthy \\
\hline Area I & 10 & 10 & 10 & healthy \\
\hline Area II & 10 & 10 & 10 & healthy \\
\hline Area III & 10 & 10 & 10 & healthy \\
\hline Area IV & 10 & 10 & 10 & healthy \\
\hline Area V & 10 & 10 & 10 & healthy \\
\hline Area VI & 10 & 10 & & 10 \\
\hline
\end{tabular}

Table 6 Evaluation of biological forms

\begin{tabular}{|c|c|c|c|c|c|c|c|}
\hline \multirow{2}{*}{ Area code } & \multicolumn{9}{|c|}{ Target assignment } & \multirow{2}{*}{$\begin{array}{c}\text { the health index of } \\
\text { biological forms }\end{array}$} & level \\
\cline { 2 - 7 } & $\mathrm{Hg}$ & $\mathrm{Cd}$ & $\mathrm{Pb}$ & $\mathrm{As}$ & $\begin{array}{c}\text { Petroleum } \\
\text { hydrocarbons }\end{array}$ & 7 & healthy \\
\hline Area I & 5 & 5 & 5 & 10 & 10 & 10 & healthy \\
\hline Area II & 5 & 5 & 5 & 10 & 10 & 7 & healthy \\
\hline Area III & 5 & 5 & 5 & 10 & 10 & 7 & healthy \\
\hline Area IV & 5 & 5 & 5 & 10 & 10 & 7 & healthy \\
\hline Area V & 5 & 5 & 5 & 10 & 10 & 10 & healthy \\
\hline Area VI & 5 & 5 & 5 & 10 & 10 & 7 & 7 \\
\hline
\end{tabular}




\subsection{Organisms}

Cangzhou nearshore index of organisms evaluation results are shown in table 7 . It can be seen from table 7 that half of the coastal areas are in a sub-healthy state and half in an unhealthy state. It shows that the coastal Marine biological environment has been damaged to varying degrees. The reclamation area (area III) and its northwest adjacent area (Area I) had the lowest biohealth index, which was mainly related to the low biomass of benthic organisms and plankton.

The reclamation activities in Cangzhou Bohai New Area are carried out from southeast to northwest, which makes the biological environment of area I, adjacent to the reclamation area III, also affected by the reclamation activities. Analysis shows that the destruction of organisms caused by reclamation activities is obvious, which is directly reflected in the biomass reduction of benthic organisms and plankton.

Table 7 Evaluation of Biohealth index

\begin{tabular}{|c|c|c|c|c|c|c|c|c|}
\hline \multirow[b]{2}{*}{ Area code } & \multicolumn{6}{|c|}{ Target assignment } & \multirow{2}{*}{$\begin{array}{l}\text { Biohealth } \\
\text { index }\end{array}$} & \multirow[b]{2}{*}{ Level } \\
\hline & $\begin{array}{c}\text { Phytoplankto } \\
\text { n density }\end{array}$ & $\begin{array}{c}\text { Zooplankton } \\
\text { density }\end{array}$ & $\begin{array}{c}\text { Zooplankton } \\
\text { biomass }\end{array}$ & $\begin{array}{l}\text { Benthic } \\
\text { density }\end{array}$ & $\begin{array}{l}\text { Benthic } \\
\text { biomass }\end{array}$ & $\begin{array}{l}\text { Density of fish } \\
\text { eggs and larvae }\end{array}$ & & \\
\hline Area I & 10 & 10 & 30 & 10 & 10 & 10 & 13.33 & Unhealthy \\
\hline Area II & 10 & 10 & 10 & 10 & 50 & 10 & 16.67 & Unhealthy \\
\hline Area III & 10 & 10 & 10 & 30 & 10 & 10 & 13.33 & Unhealthy \\
\hline Area IV & 10 & 10 & 50 & 10 & 30 & 10 & 20.00 & sub-healthy \\
\hline Area V & 10 & 10 & 30 & 50 & 10 & 10 & 20.00 & sub-healthy \\
\hline Area VI & 10 & 10 & 50 & 10 & 50 & 10 & 23.33 & sub-healthy \\
\hline
\end{tabular}

\subsection{Biological habitat}

Cangzhou nearshore index of habitat evaluation results are shown in table 7 . It can be seen from table 7 that except for area III (reclamation area), which is in an unhealthy state, all the other areas are in a sub-healthy state.

Since 2012, the total reclamation area of Area III (reclamation area) has been 32.8 square kilometers, all of which are coastal wetlands. Therefore, the index of reduction of coastal wetland area is assigned as 5 .

With the implementation of the reclamation project, the topography of the coastal area in Cangzhou also changed significantly, and the hydrodynamic environment and the sediment environment also changed, resulting in the change of sediment particle size.
Therefore, the annual variation index of the content of the main components in the sediments in each region was all 5, which was also the main reason for the subhealth of the habitat environment in most of the coastal area in Cangzhou.

\subsection{Marine ecosystem}

Cangzhou nearshore index of habitat evaluation results are shown in table 7.The evaluation results of Marine ecosystem in the coastal waters of Cangzhou are shown in Table 9, and the contour map of Marine ecosystem health index in the coastal waters of Cangzhou is shown in Figure 2.

Table8 Habitat environmental assessment

\begin{tabular}{|c|c|c|c|c|}
\hline \multirow{2}{*}{ Area code } & \multicolumn{2}{|c|}{ Target assignment } & \multirow{2}{*}{$\begin{array}{c}\text { Habitat environmental } \\
\text { health index }\end{array}$} & Level \\
\cline { 2 - 4 } & $\begin{array}{c}\text { Coastal wetland habitat } \\
\text { decreased in 5 years }\end{array}$ & $\begin{array}{c}\text { Annual variation of major } \\
\text { components in sediment }\end{array}$ & 10.00 & sub-healthy \\
\hline Area I & 15.00 & 5.00 & 10.00 & sub-healthy \\
\hline Area II & 15.00 & 5.00 & 5.00 & Unhealthy \\
\hline Area III & 5.00 & 5.00 & 10.00 & sub-healthy \\
\hline Area IV & 15.00 & 5.00 & 10.00 & sub-healthy \\
\hline Area V & 15.00 & 5.00 & 10.00 & sub-healthy \\
\hline Area VI & 15.00 & 5.00 & & \\
\hline
\end{tabular}

Table 9 Marine ecosystem assessment

\begin{tabular}{|c|c|c|c|c|c|c|c|}
\hline $\begin{array}{l}\text { Area } \\
\text { code }\end{array}$ & $\begin{array}{c}\text { Sea water } \\
\text { Environmental } \\
\text { Health Index }\end{array}$ & $\begin{array}{c}\text { Sediment } \\
\text { environmental } \\
\text { health index }\end{array}$ & $\begin{array}{l}\text { The forms of } \\
\text { health index }\end{array}$ & $\begin{array}{c}\text { Habitat } \\
\text { environmental } \\
\text { health index }\end{array}$ & Biohealth index & $\begin{array}{c}\text { Marine } \\
\text { ecosystem } \\
\text { Health index }\end{array}$ & Level \\
\hline Area I & 12.75 & 10 & 7 & 10 & 13.33 & 53.08 & sub-healthy \\
\hline Area II & 13.00 & 10 & 7 & 10 & 16.67 & 56.67 & sub-healthy \\
\hline Area III & 12.44 & 10 & 7 & 5 & 13.33 & 47.78 & Unhealthy \\
\hline Area IV & 13.00 & 10 & 7 & 10 & 20.00 & 60.00 & sub-healthy \\
\hline Area V & 12.80 & 10 & 7 & 10 & 20.00 & 59.80 & sub-healthy \\
\hline Area VI & 13.00 & 10 & 7 & 10 & 23.33 & 63.33 & sub-healthy \\
\hline
\end{tabular}




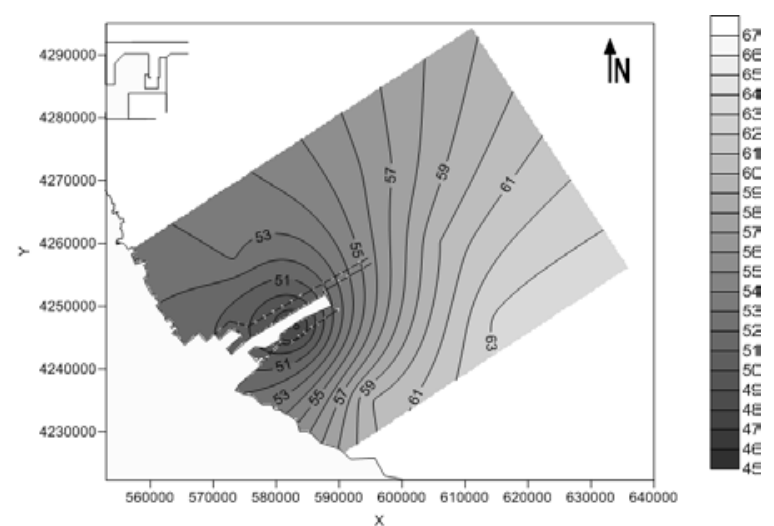

Figure2 Contour map of ecological health index (In 2017)

As can be seen from Table 8, except for area III (reclamation area), which is in an unhealthy state, the rest of the areas are in a sub-healthy state. It shows that the Marine ecosystem has been damaged to different degrees, especially the impact of reclamation activities on the Marine ecosystem.

According to the analysis in Figure 2, the whole survey area is basically in a sub-health state. In the regional distribution, the nearshore is lower than the open sea, and the reclamation area is in the low value area. The coastal wetland habitat is reduced due to land reclamation, which results in its biological habitat health index lower than the surrounding area, and this is also the main reason for its low ecological health index.

\section{CONCLUSION}

According to the results of this study, in 2017, most of the Marine ecosystems in the coastal area of Cangzhou were treated as sub-healthy, while the reclamation areas were unhealthy. By comparing the different zones, it can be seen that reclamation activities are related to the deterioration of seawater quality, the biomass reduction of benthic organisms and plankton, and the destruction of biological habitats is the main reason for the low ecosystem health index.

\section{REFERENCES}

1. Liu, W., Liu, B.(2008) Current situation, problems and control countermeasures of reclamation in China. J. Guangzhou Environmental Science., 23(2):26-30 .

2. Sun, L., Liu, H., Yang, Y., et al.(2010) Comparative study on the management of central and peripheral reclamation. J. Journal of Ocean University of China: Social Sciences edition.,5:40-46.

3. Chen, F, Wu, Y, Chen, S.(2012) Research on development trend and driving mechanism of reclamation in Fujian province. J. Chinese land science., 26(5):23-29.

4. Hu, X., Zhou, X., Liu, F., et al.(2009) Research on environmental problems caused by land reclamation and its management countermeasures. J. Marine development and management., 26(10):80-86.

5. Zhang, M., Chen, C., Su, A., et al. (2012) Research progress in marine environmental impact of reclamation. J. Journal of Ecological Environment, 21(8):1509-1513. 